\title{
KUALITAS AIR IRIGASI PADA KAWASAN INDUSTRI DI KECAMATAN KEBAKKRAMAT KABUPATEN KARANGANYAR
}

\author{
Sari Mukti Rohmawati ${ }^{1)}$, Sutarno $^{2)}$, Mujiyo ${ }^{2)}$ \\ ${ }^{1)}$ Mahasiswa Program Studi Agroteknologi, Fakultas Pertanian, Universitas Sebelas Maret \\ ${ }^{2)}$ Program Studi Ilmu Tanah, Fakultas Pertanian, Universitas Sebelas Maret \\ Email: sarimukti8@gmail.com
}

\begin{abstract}
Subdistrict Kebakkaramat was the region with the most extensive area of rice fields and the highest rice production, in addition to the Subdistricts Kebakkramat a number of industrial areas with the greatest number two after Jaten Subdistricts. Industry in the Subdistrict Kebakkramat is dominated by the textile industry and agriculture are mostly located in areas suspected of liquid waste that contaminate irrigation water for paddy soil. Pollution caused by industrial waste, will reduce the quality of irrigation water. The purpose of this study was to determine the quality of irrigation water in the industrial area Subdistricts Kebakkaramat. This research used descriptive quantitative method implemented through field surveys and continued by laboratorium analysis. Observation variables of the quality of irrigation water include temperature, TDS, $p H, D H L, D O$, nitrate and metals $C r$. The results showed that the TDS, $p H, D H L, D O$ and nitrate water still in suitable with the irrigation water quality standards according to Government Regulation No. 82 of 2001, while the temperature in point 5 does not correspond to irrigation water quality standard. $\mathrm{Cr}$ at all observation points, except the control does not correspond to irrigation water quality standard, that exceeds a predetermined limit is $0.01 \mathrm{ppm}$
\end{abstract}

Keywords: Cr, industrial, irrigation water quality standards, paddy soil, waste

\section{PENDAHULUAN}

Kualitas air adalah sifat air dan kandungan makhluk hidup, zat, energi atau komponen lain di dalam air (Sahabuddin et al. 2014). Kualitas air secara umum ditunjukkan oleh mutu atau kondisi air yang dikaitkan dengan suatu kegiatan atau keperluan tertentu. Dengan demikian kualitas air akan berbeda dari suatu kegiatan ke kegiatan lain, sebagai contoh kualitas air untuk keperluan irigasi berbeda dengan kualitas air untuk keperluan air minum (Sudaryono 2004).

Irigasi adalah kegiatan penyediaan dan pengaturan air untuk memenuhi kepentingan pertanian dengan memanfaatkan air yang berasal dari permukaan dan air tanah (Kartasapoetra dan Sutedjo 1994). Sumber irigasi dapat berupa air permukaan dan air tanah. Sumber irigasi permukaan meliputi sungai, waduk, dan danau. Air irigasi yang digunakan untuk pertanian sebaiknya memenuhi baku mutu air irigasi sesuai Peraturan Pemerintah Nomor 82 tahun 2001 termasuk dalam kelas IV sehingga kualitas air irigasi layak dijadikan pengairan untuk tanaman.

Kecamatan Kebakkramat merupakan wilayah penghasil produksi padi terbesar di
Kabupaten Karanganyar dan juga wilayah dengan jumlah industri yang paling banyak setelah Kecamatan Jaten. Industri di Kecamatan Kebakkramat didominasi oleh industri tekstil yang diduga membuang limbah cair ke sungai dan saluran air irigasi. Sawah di Kecamatan Kebakkramat merupakan sawah dengan irigasi teknis. Pada musim kemarau seperti saat ini petani mengairi sawahnya langsung dari air sungai dan saluran air menggunakan pompa diesel. Suganda et al. (2002) menjelaskan air sungai yang teraliri limbah industri dapat menurunkan kualitas dan produktivitas lahan sawah dan kualitas hasil tanaman.

Potensi logam berat yang terdapat dalam air irigasi ini diduga adalah logam $\mathrm{Cr}$ karena $52 \%$ industri di Kecamatan Kebakkramat adalah industri tekstil yang menghasilkan limbah salah satunya adalah logam berat $\mathrm{Cr}$. Penelitian ini dilakukan untuk mengetahui kualitas air irigasi di kawasan industri Kebakkramat. Penelitian ini diharapkan dapat memberikan informasi dan penyuluhan kepada masyarakat mengenai penggunaan air irigasi, pemangku kebijakan, juga dapat dijadikan pertimbangan pengelolaan dan pembuangan limbah agar tidak terjadi pencemaran terhadap 
irigasi persawahan yang dapat menurunkan kualitas dan produktivitas tanah. Kualitas air irigasi penting diketahui sebagai upaya pengelolaan dan penggunaan air irigasi oleh masyarakat untuk pengairan lahan sawah.

\section{METODE PENELITIAN}

Penelitian ini merupakan penelitian deskriptif kuantitatif yang dilaksanakan melalui survei lapang. Untuk mengetahui kualitas air irigasi di kawasan industri Kebakkramat dilakukan pengambilan sampel air di irigasi yang diduga tercemar limbah industri. Penelitian ini dilakukan selama satu periode musim tanam padi dan pengambilan sampel air dilakukan sebanyak 2 kali.

Penentuan titik sampel dilakukan secara sengaja (purposive sampling). Pemilihan titik ditentukan dengan memilih 8 (delapan) pasangan titik sampel yang masing-masing terdiri dari titik sampel air di saluran irigasi (titik $\mathrm{A}=$ air masuk) dan titik sampel air di lahan sawah yang teraliri (titik B = air sawah), dan sebagai kontrol diambil 1 (satu) pasangan titik sampel Air Irigasi dan Air Sawah yang berada di luar kawasan industri. Penentuan titik sampel dilakukan melalui proses pemetaan menggunakan aplikasi Arcview GIS 3.3 di Laboratorium Pedologi dan Survei Tanah seperti tersaji pada gambar 1 .

Pengamatan parameter kualitas air irigasi berupa parameter fisika dan kimia. Parameter fisika yang diamati meliputi suhu air dan Total Dissolved Solids (TDS). Parameter kimia yang diamati berupa $\mathrm{pH}$, Daya Hantar Listrik (DHL) air, Nitrat, Dissolved Oxygen (DO) dan logam
Cr. Pengamatan dilakukan di aliran irigasi dan air irigasi yang telah masuk pada area sawah. Analisis yang dilakukan secara langsung di lapang adalah pengukuran suhu menggunakan termometer, pengukuran TDS menggunakan TDS meter, pengukuran $\mathrm{pH}$ menggunakan $\mathrm{pH}$ meter dan pengukuran DO menggunakan DO meter.

Analisis laboratorium meliputi analisis DHL, nitrat, dan logam Cr. Pengukuran DHL menggunakan DHL meter, sedangkan analisis nitrat dilakukan secara langsung dengan cara spektofotometri yang merujuk pada Balai Penelitian Tanah (2005). Secara teknis, pengujian nitrat meliputi pemipetan $5 \mathrm{ml}$ sampel air dalam tabung kimia, bersamaan dengan digojog maka ditambahkan $0,5 \mathrm{ml}$ larutan brusin $2 \%$ dan $5 \mathrm{ml}$ asam sulfat pekat. Lalu, dibiarkan selama satu jam kemudian membacanya pada spektofotometer dengan panjang gelombang $432 \mathrm{~nm}$, serta membandingkannya dengan deret standarnya. Analisis logam berat $\mathrm{Cr}$ dilakukan secara spektofotometri serapan atom nyala. Ekstraksi sampel dilakukan dengan cara $5 \mathrm{ml}$ asam nitrat ditambahkan ke dalam sampel air yang dipipet $200 \mathrm{ml}$ dalam gelas piala kemudian dipanaskan hingga 15 sampai $20 \mathrm{ml}$ dan diencerkan dalam labu ukur $50 \mathrm{ml}$ hingga tanda tera. Kemudian disaring dan dianalisis menggunakan Atomic Absorption Spectrometry (AAS) (SNI 2009)

Penentuan kesesuaian kualitas air irigasi dengan membandingkan parameter yang diamati menurut baku mutu kualitas air sungai sebagai air irigasi menurut PP Nomor 82 Tahun 2001 dan pengklasifikasian kualitas air irigasi bedasarkan FAO (1994). 


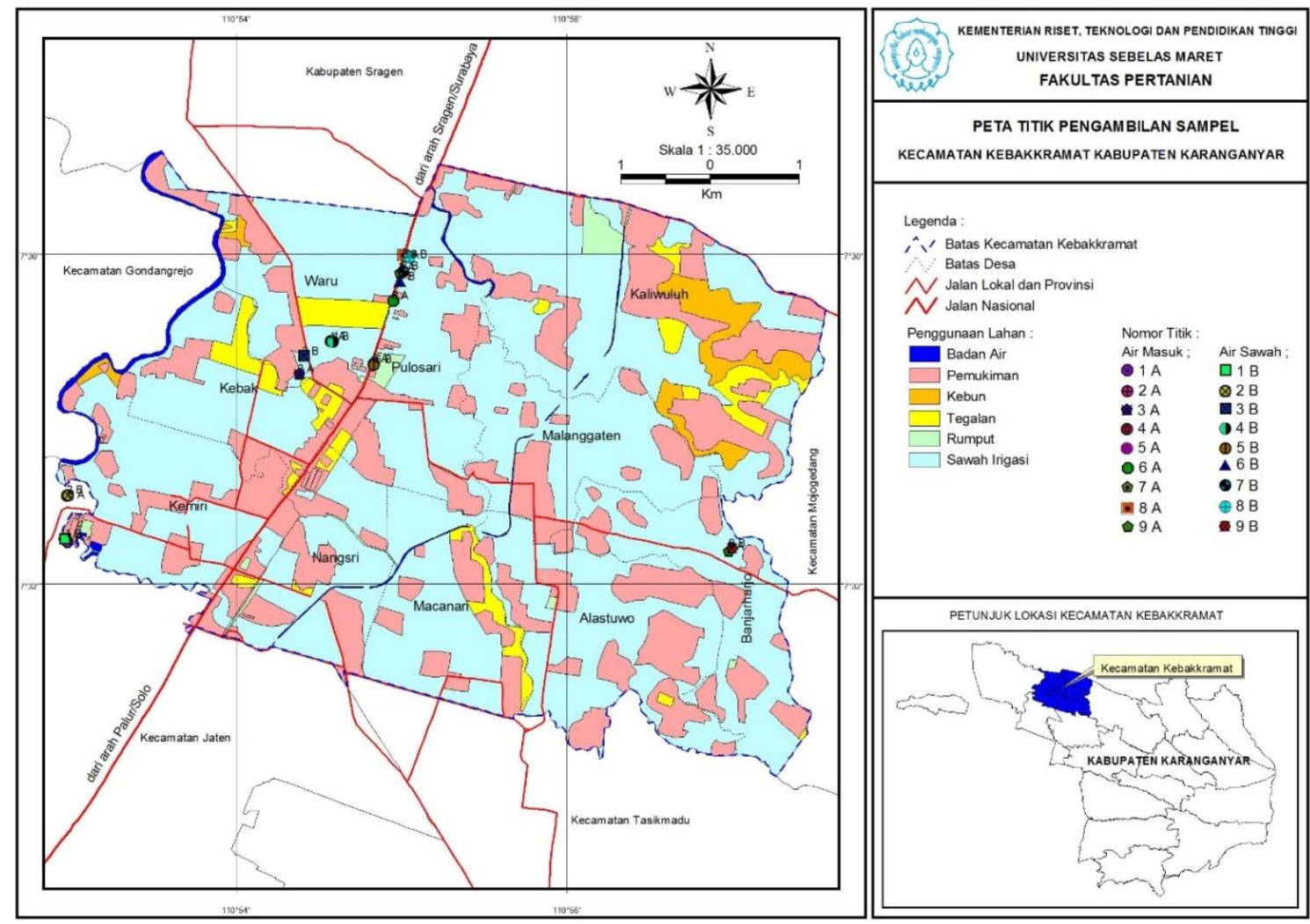

Gambar 1. Peta titik pengambilan sampel

HASIL DAN PEMBAHASAN

\section{Parameter Fisika}

Pada tabel 1 menunjukkan deviasi suhu, TDS dan DHL air yang berada pada aliran irigasi (air masuk) dan air sawah. Deviasi suhu merupakan selisih suhu air dan suhu udara. Berdasarkan tabel 1 menunjukkan deviasi suhu paling besar adalah pada titik 5 yaitu $5,5^{\circ} \mathrm{C}$ yang berarti tidak sesuai baku mutu karena berada di atas standar baku mutu air yaitu sebesar $5{ }^{\circ} \mathrm{C}$, sedangkan pada titik lainnya berada pada $0,5-3,5^{\circ} \mathrm{C}$. Pada pengamatan suhu air di 9 titik pengamatan menunjukkan suhu air minimum terjadi pada titik 3 yaitu $27,5^{\circ} \mathrm{C}$ dan suhu maksimum ada pada titik 1 yaitu $33{ }^{\circ} \mathrm{C}$. Effendi (2003) menjelaskan kisaran suhu optimum bagi pertumbuhan fitoplankton di perairan adalah $20^{\circ} \mathrm{C}-30^{\circ} \mathrm{C}$.

Pada tabel 1 menunjukkan deviasi suhu, TDS dan DHL air yang berada pada aliran irigasi (air masuk) dan air sawah. Deviasi suhu merupakan selisih suhu air dan suhu udara. Berdasarkan tabel 1 menunjukkan deviasi suhu paling besar adalah pada titik 5 yaitu $5,5^{\circ} \mathrm{C}$ yang berarti tidak sesuai baku mutu karena berada di atas standar baku mutu air yaitu sebesar $5{ }^{\circ} \mathrm{C}$, sedangkan pada titik lainnya berada pada $0,5-3,5^{\circ} \mathrm{C}$. Pada pengamatan suhu air di 9 titik pengamatan menunjukkan suhu air minimum terjadi pada titik 3 yaitu $27,5^{\circ} \mathrm{C}$ dan suhu maksimum ada pada titik 1 yaitu $33{ }^{\circ} \mathrm{C}$. Effendi (2003) menjelaskan kisaran suhu optimum bagi pertumbuhan fitoplankton di perairan adalah $20^{\circ} \mathrm{C}-30^{\circ} \mathrm{C}$. 
Kualitas Air Irigasi pada Kawasan Industri ... Rohmawati et al.

Tabel 1. Kualitas air irigasi pada kawasan industri di Kecamatan Kebakkramat

\begin{tabular}{|c|c|c|c|c|c|c|c|c|c|}
\hline Titik & Lokasi & $\begin{array}{l}\text { Suhu } \\
\text { air } \\
\left({ }^{\circ} \mathrm{C}\right)\end{array}$ & $\begin{array}{c}\text { Suhu } \\
\text { udara } \\
\left({ }^{\circ} \mathrm{C}\right)\end{array}$ & $\begin{array}{c}\text { Deviasi } \\
\text { suhu } \\
\left({ }^{\circ} \mathrm{C}\right)\end{array}$ & $\begin{array}{l}\text { Harkat } \\
\left(<5^{\circ} \mathrm{C}\right)\end{array}$ & $\begin{array}{c}\text { Total } \\
\text { dissolved } \\
\text { solids } \\
(\mathrm{TDS})(\mathrm{mg} / \mathrm{L})\end{array}$ & $\begin{array}{c}\text { Harkat } \\
(<2000 \\
\mathrm{mg} / \mathrm{L})\end{array}$ & $\begin{array}{c}\text { DHL } \\
(\mathrm{dS} / \mathrm{m})\end{array}$ & $\begin{array}{c}\text { Harkat* } \\
(0-3 \\
\mathrm{dS} / \mathrm{m})\end{array}$ \\
\hline \multirow[t]{2}{*}{1} & $\mathrm{~A}$ & 33 & 31 & 2,0 & Sesuai & $1.323,0$ & Sesuai & 1,67 & Sesuai \\
\hline & B & 30 & 31 & 1,0 & Sesuai & $1.150,0$ & Sesuai & 1,68 & Sesuai \\
\hline \multirow[t]{2}{*}{2} & A & 32,5 & 29,5 & 3,0 & Sesuai & $1.560,5$ & Sesuai & 2,19 & Sesuai \\
\hline & B & 32,5 & 29,5 & 3,0 & Sesuai & $1.475,0$ & Sesuai & 1,60 & Sesuai \\
\hline \multirow[t]{2}{*}{3} & A & 28,5 & 32 & 3,5 & Sesuai & 390,5 & Sesuai & 0,59 & Sesuai \\
\hline & B & 27,5 & 32 & 4,5 & Sesuai & 412,5 & Sesuai & 0,57 & Sesuai \\
\hline \multirow[t]{2}{*}{4} & A & 30 & 33 & 3,0 & Sesuai & 379,5 & Sesuai & 0,49 & Sesuai \\
\hline & B & 31,5 & 33 & 1,5 & Sesuai & 312,0 & Sesuai & 0,57 & Sesuai \\
\hline \multirow[t]{2}{*}{5} & A & 29 & 34,5 & 5,5 & $\begin{array}{l}\text { Tidak } \\
\text { sesuai }\end{array}$ & 867,5 & Sesuai & 1,18 & Sesuai \\
\hline & B & 29 & 34,5 & 5,5 & $\begin{array}{l}\text { Tidak } \\
\text { sesuai }\end{array}$ & 505,0 & Sesuai & 0,79 & Sesuai \\
\hline \multirow[t]{2}{*}{6} & A & 31,5 & 31 & 0,5 & Sesuai & $1.295,0$ & Sesuai & 0,67 & Sesuai \\
\hline & B & 28,5 & 31 & 2,5 & Sesuai & 740,5 & Sesuai & 1,09 & Sesuai \\
\hline \multirow[t]{2}{*}{7} & A & 31 & 30,5 & 0,5 & Sesuai & $1.410,0$ & Sesuai & 0,66 & Sesuai \\
\hline & B & 30 & 30,5 & 0,5 & Sesuai & 807,5 & Sesuai & 0,80 & Sesuai \\
\hline \multirow[t]{2}{*}{8} & A & 30 & 31 & 1,0 & Sesuai & 914,5 & Sesuai & 1,01 & Sesuai \\
\hline & B & 30,5 & 31 & 0,5 & Sesuai & 624,0 & Sesuai & 1,14 & Sesuai \\
\hline \multirow[t]{2}{*}{ Kontrol } & A & 29,5 & 31 & 1,5 & Sesuai & 199,0 & Sesuai & 0,30 & Sesuai \\
\hline & B & 29 & 31 & 2,0 & Sesuai & 187,0 & Sesuai & 0,29 & Sesuai \\
\hline
\end{tabular}

Sumber : Analisis lapang.

Keterangan : Pengharkatan berdasarkan PP RI No. 82 Tahun 2001

*. Pengharkatan berdasarkan FAO Tahun 1994

$\mathrm{A}=$ air masuk, $\mathrm{B}=$ air sawah

Suhu perairan merupakan faktor pembatas dari proses produksi di perairan. Suhu yang terlalu tinggi dapat merusak jaringan tubuh fitoplankton, sehingga akan mengganggu proses fotosintesa dan menghambat pembuatan ikatan-ikatan organik yang kompleks dari bahan organik yang sederhana serta akan mengganggu kestabilan perairan itu sendiri (Yuningsih et al. 2014)

Nilai TDS terbesar adalah pada titik 2 yaitu $1.560,5 \mathrm{mg} / \mathrm{L}$ tetapi masih berada di bawah ambang batas baku mutu air irigasi, sedangkan nilai TDS terendah adalah pada kontrol yaitu $199 \mathrm{mg} / \mathrm{L}$. Hal tersebut menunjukkan bahwa air irigasi pada titik 2 memiliki kualitas air yang lebih rendah daripada titik kontrol karena pada titik 2 berada pada kawasan industri yang mendapatkan banyak hasil buangan industri. Seperti yang dijelaskan oleh Effendi (2003) bahwa nilai TDS perairan sangat dipengaruhi oleh pelapukan batuan, limpasan dari tanah, dan pengaruh antropogenik (berupa limbah domestik dan industri)

Berdasarkan tabel 1 menunjukkan deviasi suhu paling besar pada air sawah adalah pada titik 5 yaitu $5,5^{\circ} \mathrm{C}$ yang berarti berada di atas standar baku mutu air yaitu sebesar $5{ }^{\circ} \mathrm{C}$, sedangkan pada titik lainnya berada pada $0,5-$ $3,5^{\circ} \mathrm{C}$. Nilai TDS terbesar adalah pada titik 2 yaitu $1.475 \mathrm{mg} / \mathrm{L}$ tetapi masih berada di bawah ambang baku mutu air irigasi, sedangkan nilai TDS terendah adalah pada kontrol yaitu 187 $\mathrm{mg} / \mathrm{L}$. Hal tersebut menunjukkan pada titik 2 buangan/limbah industri sangat berpengaruh terhadap nilai TDS, meskipun TDS pada air sawah lebih kecil daripada TDS air masuk. Air irigasi pada titik 2 memiliki warna kecoklatan hampir hitam dan aroma yang menyengat, sehingga wajar jika nilai TDS sangat besar.

Daya hantar listrik (DHL) adalah gambaran numerik dari kemampuan air untuk meneruskan aliran listrik. Oleh karena itu, semakin banyak garam-garam terlarut yang dapat terionisasi, semakin tinggi pulai nilai DHL. Hal ini sama seperti yang disampaikan Ariyanto dan Widijanto (2008) bahwa nilai DHL yang tinggi didominasi oleh adanya garam-garam. Tabel 2 menunjukkan nilai DHL air masuk tertinggi ada pada titik 2 yaitu 2,188 $\mathrm{dS} / \mathrm{m}$ dan nilai DHL terendah adalah pada titik kontrol yaitu $0,305 \mathrm{dS} / \mathrm{m}$.

DHL pada air sawah tertinggi adalah pada titik 1 yaitu $1,682 \mathrm{dS} / \mathrm{m}$ dan nilai DHL terendah 
sama seperti air masuk yaitu pada titik kontrol sebesar 0,288 dS/m. Dari tabel 2 menunjukkan bahwa DHL air sawah lebih rendah daripada air masuk, kemungkinan hal ini disebabkan karena garam-garam terlarut yang berada pada tanah sawah diserap oleh tanaman padi sehingga nilai DHL rendah.

Parameter Kimia Anorganik

Tabel 2. Kualitas air irigasi pada kawasan industri di Kecamatan Kebakkramat

\begin{tabular}{|c|c|c|c|c|c|c|c|c|c|}
\hline Titik & $\begin{array}{c}\text { Lokas } \\
\text { i }\end{array}$ & $\mathrm{pH}$ & $\begin{array}{c}\text { Harkat } \\
(5-9)\end{array}$ & $\begin{array}{c}\mathrm{DO} \\
(\mathrm{mg} / \mathrm{L})\end{array}$ & $\begin{array}{c}\text { Harkat } \quad(0= \\
\text { angka batas } \\
\text { minimum })\end{array}$ & $\begin{array}{l}\text { Nitrat } \\
(\mathrm{mg} / \mathrm{L}) \\
\mathrm{x} 10^{-1}\end{array}$ & $\begin{array}{c}\text { Harkat } \\
(<20 \\
\mathrm{mg} / \mathrm{L})\end{array}$ & $\begin{array}{c}\text { Logam } \\
\mathrm{Cr} \\
(\mathrm{ppm}) \\
\times 10^{-1}\end{array}$ & $\begin{array}{c}\text { Harkat } \\
(<0,01 \mathrm{ppm})\end{array}$ \\
\hline \multirow[t]{2}{*}{1} & $\mathrm{~A}$ & 7,50 & Sesuai & 2,05 & Sesuai & 0,24 & Sesuai & 0,30 & Tidak sesuai \\
\hline & B & 7,40 & Sesuai & 2,25 & Sesuai & 0,55 & Sesuai & 0,75 & Tidak sesuai \\
\hline \multirow[t]{2}{*}{2} & A & 7,50 & Sesuai & 4,05 & Sesuai & 0,13 & Sesuai & 0,35 & Tidak sesuai \\
\hline & B & 7,50 & Sesuai & 3,60 & Sesuai & 0,29 & Sesuai & 0,63 & Tidak sesuai \\
\hline \multirow[t]{2}{*}{3} & A & 7,00 & Sesuai & 5,30 & Sesuai & 0,03 & Sesuai & 0,12 & Tidak sesuai \\
\hline & B & 6,80 & Sesuai & 3,70 & Sesuai & 0,03 & Sesuai & 0,15 & Tidak sesuai \\
\hline \multirow[t]{2}{*}{4} & A & 7,70 & Sesuai & 5,30 & Sesuai & 0,04 & Sesuai & 0,99 & Tidak sesuai \\
\hline & B & 8,50 & Sesuai & 5,05 & Sesuai & 0,06 & Sesuai & 0,18 & Tidak sesuai \\
\hline \multirow[t]{2}{*}{5} & A & 7,90 & Sesuai & 5,70 & Sesuai & 0,03 & Sesuai & 0,26 & Tidak sesuai \\
\hline & B & 7,80 & Sesuai & 5,25 & Sesuai & 0,04 & Sesuai & 0,50 & Tidak sesuai \\
\hline \multirow[t]{2}{*}{6} & A & 6,80 & Sesuai & 6,80 & Sesuai & 0,01 & Sesuai & 0,55 & Tidak sesuai \\
\hline & B & 7,10 & Sesuai & 5,60 & Sesuai & 0,03 & Sesuai & 0,54 & Tidak sesuai \\
\hline \multirow[t]{2}{*}{7} & A & 6,90 & Sesuai & 5,35 & Sesuai & 0,01 & Sesuai & 0,51 & Tidak sesuai \\
\hline & B & 6,60 & Sesuai & 4,90 & Sesuai & 0,02 & Sesuai & 0,20 & Tidak sesuai \\
\hline \multirow[t]{2}{*}{8} & A & 7,00 & Sesuai & 5,00 & Sesuai & 0,04 & Sesuai & 0,51 & Tidak sesuai \\
\hline & B & 6,50 & Sesuai & 4,70 & Sesuai & 0,05 & Sesuai & 0,98 & Tidak sesuai \\
\hline \multirow{2}{*}{$\begin{array}{c}\text { Kontr } \\
\text { ol }\end{array}$} & A & 7,20 & Sesuai & 7,55 & Sesuai & 0,01 & Sesuai & 0,05 & Sesuai \\
\hline & B & 7,00 & Sesuai & 7,55 & Sesuai & 0,05 & Sesuai & 0,06 & Sesuai \\
\hline
\end{tabular}

Sumber : Analisis lapang dan laboratorium.

Keterangan : Pengharkatan berdasarkan PP RI No. 82 Tahun 2001

$\mathrm{A}=$ air masuk, $\mathrm{B}=$ air keluar

DO atau dissolved oxygen adalah jumlah oksigen yang ada dalam air. Kadar oksigen yang tinggi menggambarkan kualitas air yang baik dan belum tercemar, dan sebaliknya jika rendah menggambarkan kualitas air yang jelek dan sudah tercemar. Kadar DO yang menurun mungkin diakibatkan oleh limbah domestik dan industri yang masuk ke perairan (Achmad 2011). Tabel 2 menunjukkan nilai DO air masuk tertinggi berada pada titik kontrol yaitu $7,55 \mathrm{mg} / \mathrm{L}$ dan DO terendah berada pada titik 1 yaitu sebesar $2,05 \mathrm{mg} / \mathrm{L}$ yang berarti kualitas air irigasi di titik kontrol lebih baik daripada di titik 1 yang berada di kawasan industri.

Nitrat adalah bentuk utama nitrogen di perairan alami dan merupakan nutrien utama bagi pertumbuhan tanaman dan algae. Nitrat sangat mudah larut dalam air dan bersifat labil. Nitrat dalam perairan memiliki jumlah yang sedikit (Effendi 2003). Tabel 2 menggambarkan titik 1 memiliki nilai nitrat air masuk tertinggi dari 8 titik lainnya yaitu sebesar $0,024 \mathrm{mg} / \mathrm{L}$, sedangkan nilai nitrat terendah ada pada titik 7 dan kontrol yaitu sebesar 0,001 $\mathrm{mg} / \mathrm{L}$. Hal tersebut menunjukkan bahwa nitrat di air irigasi pada semua titik masih sesuai dengan baku mutu air irigasi.

Logam $\mathrm{Cr}$ air masuk terdapat pada semua titik pengamatan, logam $\mathrm{Cr}$ tertinggi terdapat pada titik 4 yaitu sebesar 0,099 ppm, sedangkan logam $\mathrm{Cr}$ terendah berada pada titik kontrol yaitu 0,005 ppm. Logam $\mathrm{Cr}$ air masuk pada 8 titik pengamatan tidak sesuai dengan baku mutu kualitas air irigasi, hal ini menunjukkan bahwa terjadi pencemaran logam $\mathrm{Cr}$ di aliran irigasi yang berasal dari industri di kawasan tersebut. Sedangkan pada titik kontrol yang berada jauh dari kawasan industri, logam $\mathrm{Cr}$ masih sesuai dengan baku mutu. Logam $\mathrm{Cr}$ yang berada pada titik kontrol kemungkinan berasal dari pencemaran penggunaan pupuk anorganik yang mengandung logam $\mathrm{Cr}$.

Pada tabel 2 juga menunjukkan nilai $\mathrm{pH}$, DO, nitrat dan logam Cr pada air irigasi yang telah masuk pada tanah sawah. Nilai $\mathrm{pH}$ air sawah pada semua titik masih sesuai dengan baku mutu air irigasi yaitu berada pada rentang 6,5-8,5. $\mathrm{pH} 8,5$ berada pada titik 4 yang $\mathrm{pH}$ air 
masuknya adalah 7,7. $\mathrm{pH}$ air sawah lebih besar daripada $\mathrm{pH}$ air masuk kemungkinan disebabkan oleh adanya pengaruh pemberian pupuk dan pengolahan tanah sawah.

Nilai DO air sawah tertinggi berada pada titik kontrol yaitu 7,55 mg/L dan DO terendah pada titik 1 sebesar $2,25 \mathrm{mg} / \mathrm{L}$. Hal ini menunjukkan kualitas air irigasi di titik kontrol lebih baik daripada titik 1 yang berada pada kawasan industri, sedangkan titik kontrol berada jauh di luar kawasan industri, namun DO di semua titik masih sesuai dengan baku mutu air irigasi. Yuningsih et al. (2014) menjelaskan banyaknya kandungan bahan organik maupun limbah organik pada suatu perairan dapat menyebabkan oksigen terlarut rendah. Nitrat pada air sawah di semua titik pengamatan masih sesuai dengan baku mutu air irigasi.

Logam Cr pada air sawah terdapat pada semua titik pengamatan, logam $\mathrm{Cr}$ tertinggi terdapat pada titik 8 yaitu sebesar $0,098 \mathrm{ppm}$, sedangkan logam $\mathrm{Cr}$ terendah berada pada titik kontrol yaitu 0,006 ppm. Logam Cr di 8 titik pengamatan tidak sesuai baku mutu air irigasi dengan nilai $\mathrm{Cr}$ lebih dari 0,01 ppm, sedangkan pada titik kontrol masih sesuai dengan baku mutu air irigasi yaitu kurang dari 0,01 ppm.

\section{KESIMPULAN}

Kualitas air irigasi pada air masuk dan air sawah berdasarkan parameter TDS, pH, DHL, DO, dan Nitrat masih sesuai dengan baku mutu air irigasi, sedangkan pada titik 5 suhu air irigasi tidak sesuai dengan baku mutu. Logam $\mathrm{Cr}$ di air masuk dan air sawah pada titik 1 sampai 8 tidak sesuai dengan baku mutu air irigasi.

\section{DAFTAR PUSTAKA}

Achmad F 2011. Status mutu sungai cisadane sebagai air irigasi. J. Irigasi.Vol 6 (1). ISSN 1907-5545

Ariyanto DP dan Widijanto H 2008. Dampak air limbah industri Josroyo, Karanganyar terhadap kadar tembaga $(\mathrm{Cu})$ dalam air dan permukaan tanah saluran air Pungkuk.
J. Ilmiah Ilmu Tanah dan Agroklimatologi. Vol 5 No 12008.

Balai Penelitian Tanah 2005. Analisis Kimia Tanah, Tanaman, Air dan Pupuk. Bogor : Balai Penelitian Tanah

Effendi H 2003. Telaah Kualitas Air. Yogyakarta : Kanisius

Kartasapoetra AG dan Sutedjo M 1994. Teknologi Pengairan Pertanian Irigasi. Jakarta : Bumi Aksar

Peraturan Pemerintah Republik Indonesia No. 82 tahun 2001 tentang Pengelolaan Kualitas Air dan Pengendalian Pencemaran Air

Sahabuddin H, Harisuseno D dan Yulianti E. 2014. Analisa status mutu air dan daya tampung beban pencemaran Sungai Wanggu Kota Kendari. J. Teknik Pengairan. 5 (1) : 19-28

Sudaryono 2004. Pemantauan kualitas air tanah kawasan Pantai Glagah, Kabupaten Kulon Progo, DI. Jogjakarta. J. Teknik Lingkungan. 5 (3) : 198-204

Suganda H, Setyorini D, Kusnadi H, Saripin I dan Kurnia U. 2002. Evaluasi pencemaran limbah indstri tekstil untuk kelestarian lahan sawah. Prosiding Seminar Nasional Multifungsi dan Konversi Lahan Pertanian. Balai Penelitian Tanah. Bogor

Suyana J dan Widijanto H 2002. Studi kualitas air dan sumbangan hara dari irigasi Sidorejo Jawa Tengah pada budidaya padi sawah. J. Sains Tanah. Vol 1 No 2. ISSN 1412-3606

Yuningsih HD, Soedarsono P dan Anggoro S 2014. Hubungan bahan organik dengan produktivitas perairan pada kawasan tutupan eceng gondok, perairan terbuka dan keramba jaring apung di Rawa Pening Kabupaten Semarang Jawa Tengah. Diponegoro Journal Of Maquares. Vol 3 No 1 (37-43). 